\title{
Microfacies analysis of Upper Eocene shallow-water carbonates from the Rodnei Mountains (N Romania)
}

\author{
Diana SAHY1*, Emanoil SĂSĂRAN² \& Tudor TĂMAŞ,3 \\ ${ }^{1}$ Institute of Applied Geology, Department of Civil Engineering, University of Natural Resources and Applied Life Sciences, \\ Peter Jordan Strasse 70, 1190, Vienna, Austria \\ ${ }^{2}$ Department of Geology, „Babeş-Bolyai” University, Kogălniceanu 1, 400084, Cluj Napoca, Romania \\ ${ }^{3}$ „Emil Racoviţă” Institute of Speleology, Clinicilor 5, 400006, Cluj Napoca, Romania
}

Received May 2008; accepted October 2008

Available online November 2008

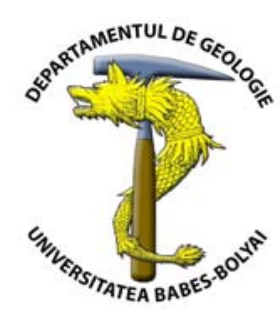

\begin{abstract}
A Priabonian carbonate ramp developed in the NW Rodnei Mountains as a part of a Paleogene sedimentary cover that overlies the metamorphic basement of the Eastern Carpathians (N Romania). Two sections, namely Iza Valley and Bătrâna Spring, were sampled at different locations along the carbonate ramp. The deposits accumulated in a shallow environment, in which relative sea level change is seen as the main controlling factor of facies distribution. A shore face $\rightarrow$ middle ramp $\rightarrow$ inner ramp transition was recorded in both sections. Associations of large benthic foraminifers and high siliciclastic input are the dominant features in the northern part of the ramp, while in the south corals and coralline algae thrived in an environment characterized by low hydrodynamic energy and clastic input. A 4-5 m thick intercalation identified in the middle ramp deposits of both studied sections shows a temporary change in fossil assemblages, with foraminifers almost completely replaced by red algae and rhodoliths, and extensive bioturbation caused by ostracods and gastropods. Towards the top of the carbonate deposits, large bivalve colonies and an increase in clastic input indicate a relative sea-level fall, which ultimately led to the cessation of carbonate sedimentation and the deposition of black shales on a basin-wide scale during the Lower Oligocene.
\end{abstract}

Keywords: shallow-water carbonates, Upper Eocene, Rodnei Mountains, benthic foraminifers, coralline algae, paleoenvironment

\section{INTRODUCTION}

During the Paleogene, shallow-water carbonates accumulated over large areas of the peri-Tethyan region, accounting for more than $80 \%$ of the global neritic carbonate production in Eocene times (Philip, 2003). Favorable geographical settings and warm climate led to increased carbonate sedimentation in temperate regions situated at more than $45^{\circ} \mathrm{N}$ latitude (Kiessling et al., 2003), with large benthic foraminifers (LBF) and coralline algae as the main sediment contributors (Nebelsick et al., 2005).

In the Tethyan region, large accumulations of LBF were generally associated with ramp settings (Buxton and Pedley, 1989) and the relative distribution of different foraminifers across carbonate ramps was used as a valuable tool in paleoenvironmental and paleobathimetric reconstructions (Cosovic et al., 2004; Barattolo et al., 2007). The distribution patterns of fossil LBF were mainly investigated by means of extrapolating environmental proxies gained from extant foraminifers (Beavington-Penney and Racey, 2004) in an attempt to derive parameters such as nutrient and oxygen availability, water chemistry and depth, hydrodynamic energy, and substrate type and stability
(Murray, 2001). An analysis of the functional morphology of foraminifera tests provides another tool for paleoenvironmental reconstructions, particularly in the case of genera lacking recent representatives. Test size and shape is influenced both by the depositional environment, and for a given species by the position that individuals occupy on the carbonate ramp in relation to the limits of their characteristic depth range. Optimal conditions are indicated by large, lenticular morphologies, while smaller, flattened tests are characteristic for communities living close to the extremes of their characteristic depth range (Geel, 2000; Cosovic et al., 2004).

In addition to biological processes, observed associations of fossil LBF were often affected by physical processes, leading to the selective removal or concentration of different components as a function of their primary skeletal porosity which can allow for easy remobilization by waves and marine currents (Racey, 2001; Jorry et al., 2006), resulting in para-autochthonous or allochthonous deposits (Aigner, 1985).

Coralline algae have been reported from a variety of Eocene depositional environments, and occupied a wider depth range than nummulitids and discocyclinids 
(Bassi, 1998; Rasser, 2000; Barattolo et al., 2007). Their value as paleo-bathymetric indicators is however diminished by the relatively small number of publications dealing with the depth distribution of modern algae and uncertainties in the taxonomy of fossil genera (Rasser and Piller, 1997). Coralline algae often occur in the form of encrustations or algal pavements developed over soft substrates, usually associated with corals (Bassi, 2005). In-situ preserved algal debris have been used in paleoecological interpretations, with growth forms indicating various degrees of hydrodynamic energy (Rasser and Piller, 2004).

LBF and coralline algae are highly sensitive to environmental changes caused by sea-level fluctuations, water chemistry and temperature changes, and siliciclastic and nutrient input provided by continental runoff (Beavington-Penney and Racey, 2004). As a consequence, the presence of foraminifers and algae in carbonate deposits provides an insight into the relative distribution of marine habitats in space and in time in response to changing environmental conditions.

The aim of this paper is to investigate the Upper Eocene to Lower Oligocene evolution of a carbonate ramp situated in the Rodnei Mountains, in the northern part of the Romanian Eastern Carpathians. The limestones were studied in two stratigraphical sections, which recorded the response of the depositional environment to fluctuating relative sea levels during the Priabonian, and the basin-wide accumulation of organic carbon rich sediments above the Eocene/Oligocene boundary.

\section{GEOLOGICAL SETTING}

\section{Distribution of Eocene carbonates in the Alpine Carpathian domain}

Eocene limestones found within the autochthonous Paleogene infill of several basins in the Alpine-Carpathian realm are remnants of carbonate sedimentation occurring on a once extensive shallow shelf that occupied the northern rim of the Tethys (Rögl, 1999). In the Eastern Alps, Late Eocene carbonates are generally small scaled and tectonically isolated (Oberhauser, 1995) and occur in intraAlpine mollase and Gosau basins (Kazmer et al., 2003). In the Alpine-Carpathian Foreland Basin, autochthonous late Eocene deposits form a laterally extensive belt of platform carbonates that was reported from France, Switzerland, Bavaria and Upper Austria (Oberhauser, 1995; Rasser, 2000).

In central Hungary and in the Western Carpathians, Middle to Upper Eocene limestones occur in the Hungarian Paleogene Basin (HPB), and the Central Carpathian Paleogene Basin (CCPB), respectively (Baldi, 1986) (Fig. 1).

Carbonate sedimentation west (Switzerland, France) and east (HPB and CCPB) of the Alpine orogen was controlled by the rate at which regional subsidence, caused by the flexural load of the Alps on the European margin, propagated to the west and east, respectively away from the Alpine orogen (Allen et al., 2001; Kazmer et al., 2003; Schmid et al., 2004). As a result, the base of the carbonate deposits is progressively younger from west to east in both HPB and CCPB (Baldi, 1986) (Fig. 1).

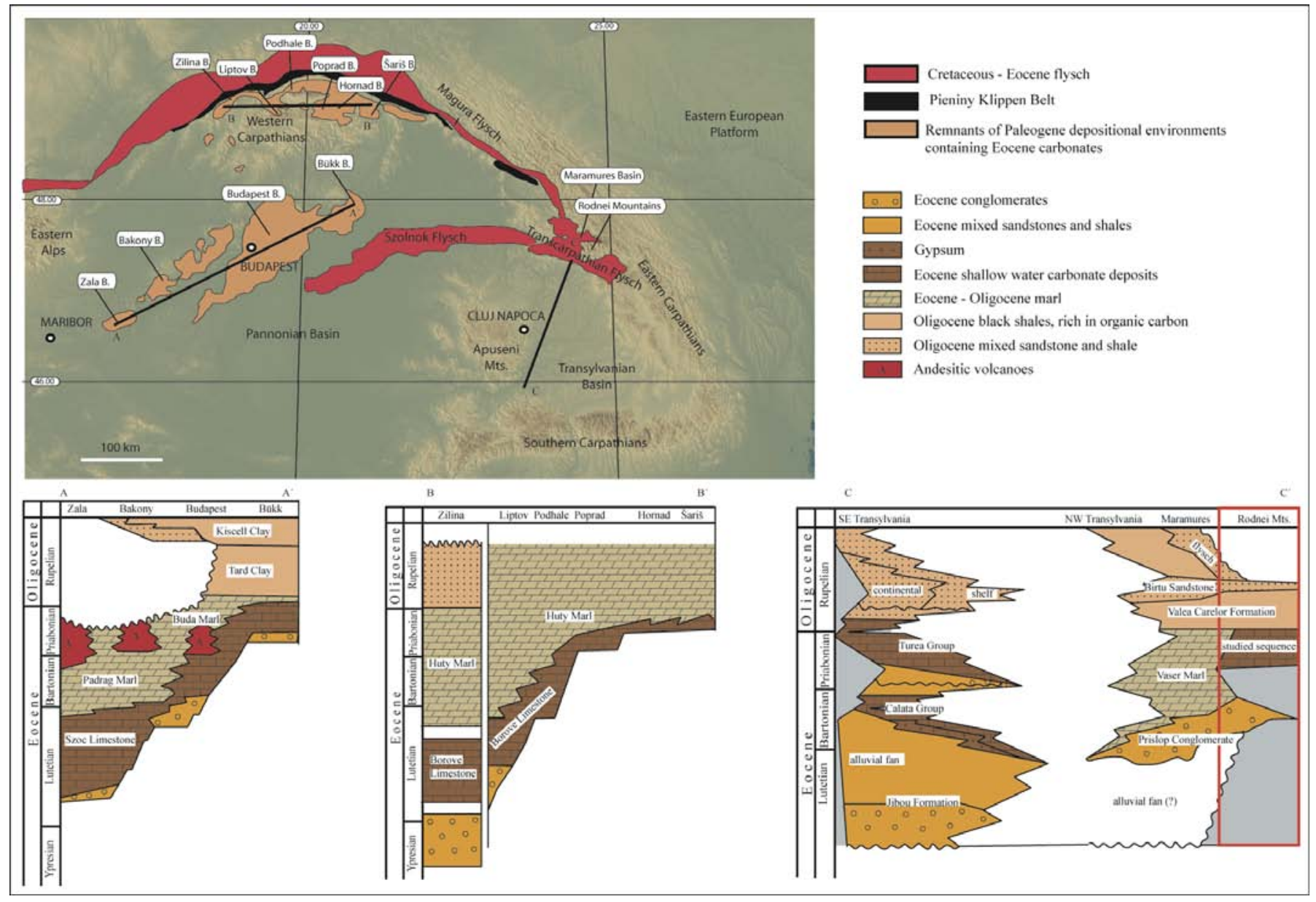

Fig. 1. Distribution and correlation of shallow-water Eocene carbonates from the Transylvanian Basin, the Western Carpathians and central Hungary (after Baldi, 1998; Kazmer et al., 2003 and Krezsek and Bally, 2006). 
In spite of their different age and locations, most Eocene carbonates from the Alpine-Carpathian-Pannonian region share a number of common characteristics: (1) they were dominantly deposited in shallow environments, (2) they are underlain by clastic material of marine or continental origin and were deposited over a major basal discontinuity which separates them from older, Mesozoic deposits, and (3) carbonate sedimentation was vertically replaced by the accumulation of deeper marine siliciclastic deposits which can be used for inter-basinal correlations (Baldi, 1986; Rasser, 2000; Allen et al., 2001).

\section{Regional stratigraphy and geological setting of the study area}

Eocene limestones from the NE Carpathians of Romania were deposited as a part of the Cenomanian - Lower Miocene sedimentary sequence of the Transcarpathian Flysch, which extends towards the west, in the $\mathrm{N}$ Transylvanian Basin (Patrulius et al., 1968). On a regional scale the Transcarpathian Flysch is regarded as both the SE extremity of the Magura Flysch belt from the Western Carpathians (Oszczypko, 2006) and the E extremity of the Szolnok Flysch (Csontos and Nagymarosi, 1998) (Fig. 1). Paleogene sedimentation in the larger context of the Transylvanian basin took place in progressively deeper environments from south to north (Krezsek and Bally, 2006). Middle to Late Eocene sedimentary successions consist of two transgressive-regressive cycles (Proust and Hosu, 1996). Siliciclastic sedimentation dominated in Lower Oligocene times, resulting in the accumulation of outer shelf and slope deposits, respectively, the Ileanda Formation in the central part of the Transylvanian Basin and the Valea Carelor Formations in $\mathrm{N}$ Transylvania and in the Transcarpathian Flysch Basin (Dicea et al., 1980). These deposits can be correlated with the Lower Oligocene deposits of the Hungarian Paleogene Basin (Tard clay) and the Central Carpathian Paleogene Basin (Huty and Zakopane formations) (Fig. 1).

During the Eocene and Oligocene, and particularly during the second transgressive - regressive cycle mentioned from the Transylvanian basin, sedimentation of the Transcarpathian Flysch extended into the western part of the Rodnei Mountains in the Eastern Carpathians. Lutetian conglomerates, Priabonian limestones, and Oligocene black shales and sandstones (Mutihac, 1990; Patrulius et al., 1955) were deposited over a basement consisting of Precambrian quartz micaschists (Kräutner et al., 1982; Balintoni, 1997) (Fig. 2).

Lutetian conglomerates consist mainly of rounded quartz pebbles and subordinately micaschist lithoclasts bound by carbonate cement and form a discontinuous, up to $1 \mathrm{~m}$ thick layer separating the metamorphic basement from the overlying limestones.

The Priabonian age was assigned to the carbonate deposits from the NW Rodnei Mountains by Patrulius et al. (1955), based on the presence of a fossil association containing Nummulites striatus, N. incrassatus, Orthophragmina ephippium, Pycnodonta brongniarti and Chlamys biarritzensis. The carbonate series forms a faulted monocline dipping $10-20^{\circ}$ west, continuous from Bătrâna Spring (SE) to the reach of Dragoş Vodă fault (NW) (Fig. 2).

The southern part of the carbonate ramp consists of massive coral-algal limestones, while its northern part is made

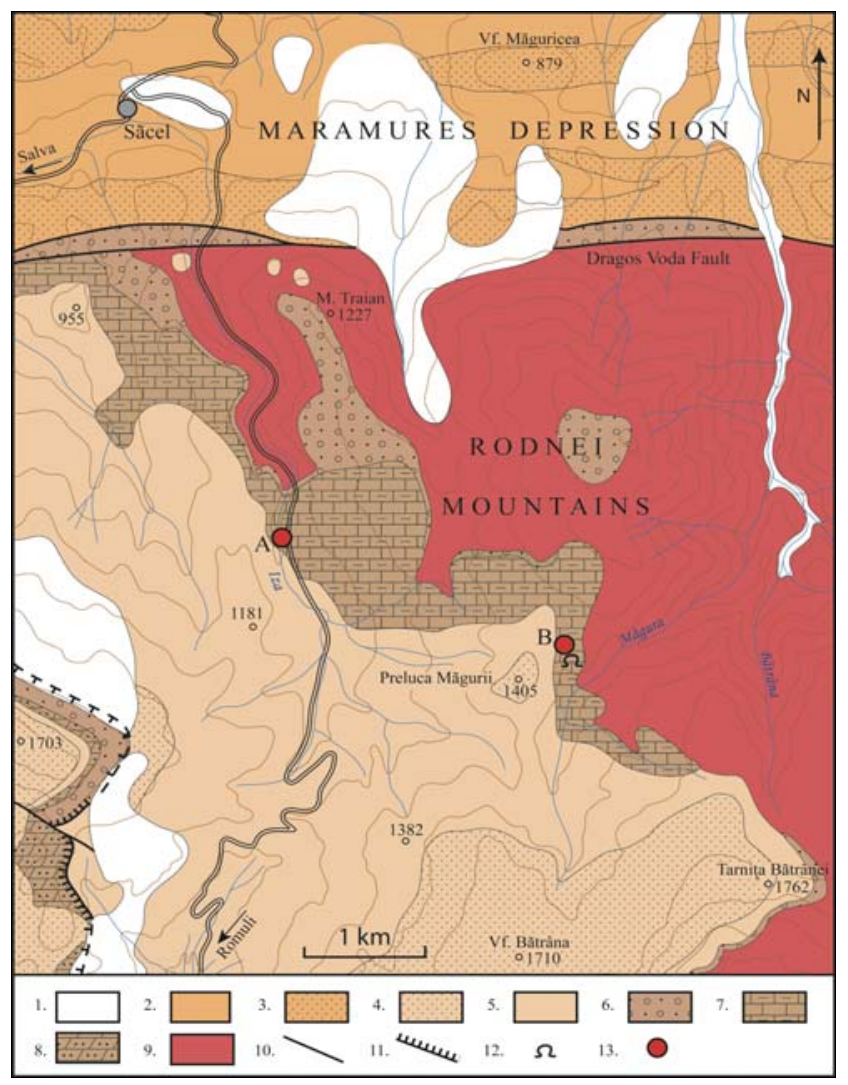

Fig. 2. Geological map of the NW part of the Rodnei Mountains (after Kräutner et al., 1982) 1 -Quaternary deposits, 2 - Upper Oligocene flysch, 3 - Borşa sandstone, 4 - Birţu sandstone (Lower Oligocene), 5 - black shales (Valea Carelor Formation, Lower

Oligocene, 6 - Lutetian conglomerates, 7 - Priabonian limestone,

8 - Eocene marls, 9 - metamorphic basement, 10 - fault,

11 - nappe, 12 - entrance of Iza Cave, 13 - locations of sections $A$ (Iza Valley) and B (Bătrâna Spring).

up of well-bedded deposits in which benthic foraminifera associations dominate (Mutihac, 1955; Patrulius et al., 1955).

In the Miocene, intense tectonic activity in the western part of the Maramureş Depression structured the sedimentary cover into a series of nappes known as the Pienides (Aroldi, 2001), while in the eastern part, the basement of the Rodnei Mountains and its sedimentary cover were uplifted along the Dragoş Vodă - Bogdan Vodă fault system (Tischler, 2005).

\section{SAMPLED SECTIONS AND METHODS}

Due to the overlying deposits, tectonics, and vegetation, there are no single outcrops exposing the entire Priabonian carbonate series in the study area. For this reason, we resorted to sampling two composite sections. The first section (Iza Valley section) was compiled from two individual outcrops located in the northern part of the carbonate ramp, along the Iza Valley, about $1 \mathrm{~km}$ downstream of the Iza karst system (Fig. 2). An outcrop spanning the lower two thirds of the carbonate deposits is located on the left bank of the Iza stream (Fig. 3a), while the top of the limestones was intercepted in an outcrop located on the opposite bank, $100 \mathrm{~m}$ upstream (Fig. 3b). The second section (Bătrâna Spring section, Fig. 2) was compiled from one surface outcrop located in the southern part of the carbonate ramp, about $3 \mathrm{~km}$ SE from the first sampled site, and from samples taken along the main passage of Iza Studia UBB, Geologia, 2008, 53 (2), 13 - 24 

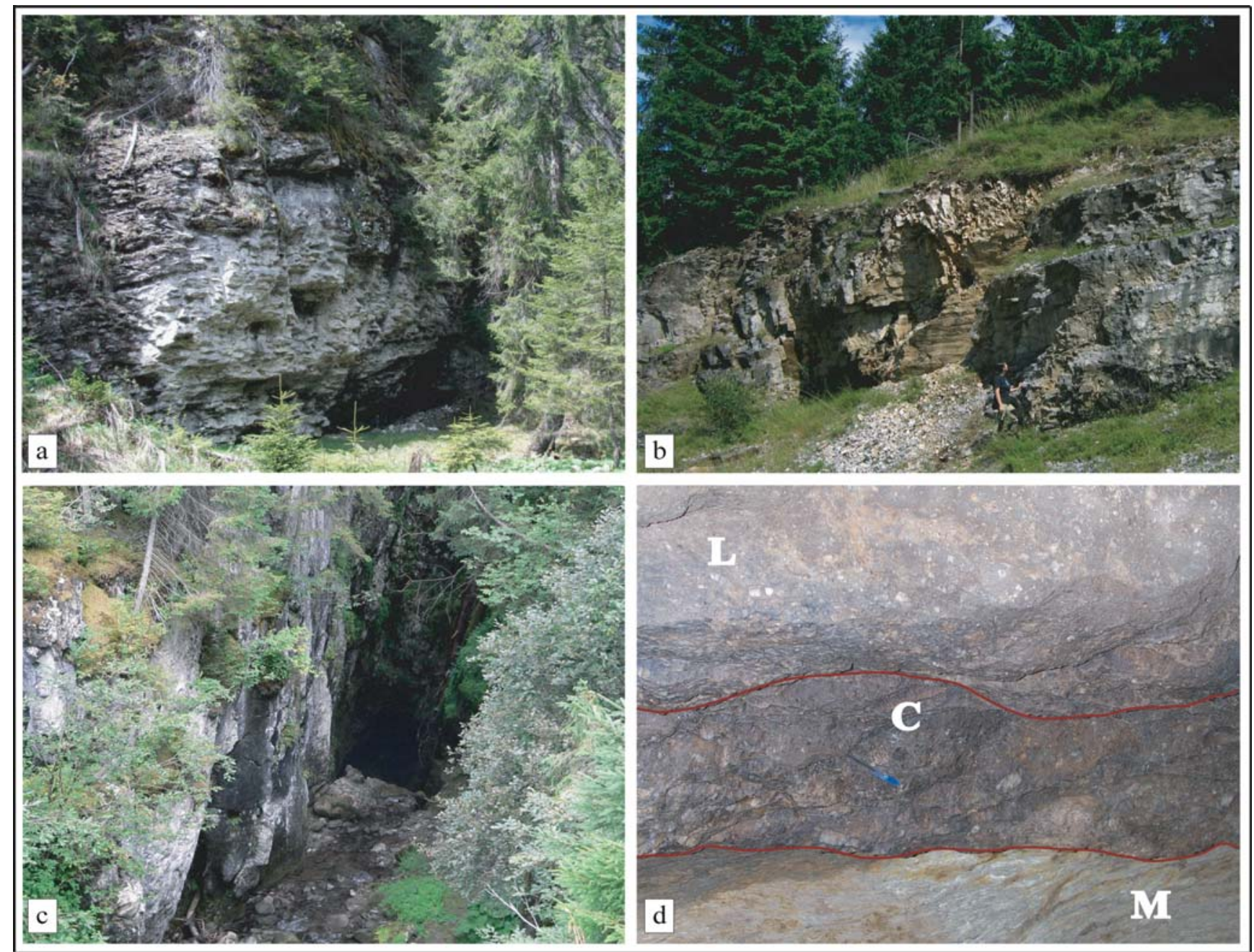

Fig. 3. a) outcrop situated on the left bank of the Iza stream, exposing the lower part of the Iza Valley carbonate deposits, b) outcrop situated on the right bank of the Iza stream exposing the upper part of the Iza Valley carbonate deposits, c) outcrops at the entrance of Iza Cave, $d$ ) the contact between the crystalline basement and the Eocene sedimentary series as seen in Iza Cave ( $M$ - Precambrian micaschist, $C$ - Lutetian conglomerates, $L$ - Priabonian limestone).

Cave (Fig. 3c), where the lower part of the limestones and the contact with the underlying formations is exposed.

All outcrops were sampled at $1 \mathrm{~m}$ intervals, except for macroscopically obvious transitions, in which case additional samples were taken directly above and below the boundary. A total of 90 thin sections were analyzed under a binocular microscope in order to identify sedimentary structures and microfossil associations.

\section{RESULTS}

The analyzed stratigraphic sections recorded marked differences between the northern and southern part of the carbonate ramp. The northern part of the ramp (Iza Valley section) is dominated by associations of large benthic foraminifers and high siliciclastic input. The southern part (Bătrâna Spring) is the only location in the area of the Transcarpathian Flysch known to expose bioconstructed limestones (Patrulius et al., 1955). The section is dominated by corals and coralline algae, pointing to an environment characterized by low hydrodynamic energy and clastic input.

\section{Iza Valley section}

Five facies types were identified in the Iza Valley section (A1 to A5 in Fig. 4). The sampled carbonate deposits have a total thickness of $46 \mathrm{~m}$, and were deposited directly over the metamorphic basement.

\section{A1. Bioclastic microconglomerate}

Relatively coarse $1 \mathrm{~m}$ thick clastic deposits appear at the base of the carbonate series and consist of quartz pebbles with angular to subangular shapes and up to $1 \mathrm{~cm}$ in diameter. Micaschist lithoclasts account for approximately $5 \%$ of the total extraclastic material. A large number of mollusk fragments, mainly gastropods and bivalves were also identified. Inter-granular spaces are filled by sparitic calcite. The microconglomerates differ from the underlying Lutetian conglomerates in terms of clast shape and size (rounded quartzite pebbles, up to $30 \mathrm{~cm}$ in diameter in the latter). Furthermore, the micro-conglomerates pass gradually into the overlying facies, unlike the Lutetian deposits identified in the Iza Cave (Viehmann et al., 1979; Tămaş et al., 2008), which are separated from the limestones by an erosional boundary (Fig. 3d). The deposits accumulated in a 
mixed carbonate - siliciclastic shore environment where high hydrodynamic energy led to the fragmentation of the mollusk shells and constant reworking of the sediment. The angular shape of the quartz and quartzite clasts indicates a sediment source that was situated relatively close to the area of the carbonate shelf.

\section{A2. Bioclastic sandstone}

The deposition of the basal conglomerate was followed by the accumulation of well-bedded bioclastic sandstones with a thickness of $20 \mathrm{~m}$. The sandstones consist of $5-30 \mathrm{~cm}$ thick beds separated by erosional surfaces and alternating with bioclastic extraclastic grainstones (10-15 cm thick) with good lateral continuity and an upward increasing frequency. The transition between the conglomerates and the sandstones is marked by a change in the size and shape of the extraclastic particles, a better sorting of the sedimentary material and the disappearance of large mollusk fragments. The extraclastic material consists of quartz sand with rounded or subangular grains and accounts for about $60 \%$ of the sediment.

Fossil assemblages within the sandstone bodies consist of echinoid plates often with syntaxial overgrowth of sparitic calcite, red algae and occasionally miliolids and fragmented tests of large benthic foraminifers. Small scale cross-laminations are frequent, and sometimes consist of 1-2 $\mathrm{mm}$ interbedded layers of quartz sandstone and fragmented bioclastic material, consisting largely $(\sim 80 \%)$ of echinoid plates.

The grainstone intercalations contain abundant assemblages of large benthic foraminifera dominated by Nummulites sp. (40-60\% of the sediments) (Pl. I, Figs. 1, 2). Individual tests ranging in diameter between $2-4 \mathrm{~mm}$ are concentrated in densely packed shoals, frequently showing imbricate structures. A small number of miliolids, echinoid plates, and algal debris are also present. Extraclastic input is reduced compared to the sandstones, only $20 \%$ of the sediment consisting of quartz sand.

The deposits accumulated in an inner ramp setting, in a mixed carbonate - siliciclastic environment. The good sorting is characteristic for highly mature sediments and well-rounded components point towards a high-energy environment, above the fair weather waves base (FWWB). Nummulites tests found in the sandstone are often fragmented, as opposed to the well-preserved tests found in the grainstones. Distinct levels of grainstones rich in nummulitids could indicate relative sea level oscillations, however the constant size of individuals and the lack of carbonate mud suggest that these deposits were either subject to intense winnowing or were deposited in an allochthonous position.

The modern equivalents of nummulitids prefer sandy substrates in the lower parts of the photic zone, characterized by low or moderate extraclastic input and sediment mobility, typically below the FWWB (Hohenegger et al., 2000). Assuming that the same ecological conditions are valid for fossil nummulitids, the presence of large numbers of tests concentrated in distinct levels throughout the sandstone could be the result of episodic remobilization of the highly buoyant bioclasts by waves or marine currents (Jorry et al., 2003). This is also supported by the monospecific character of the deposits, the presence of imbricate structures within densely packed nummulitic shoals, and the lack of encrustations, the latter suggesting continuous movement (Racey, 2001).

\section{A3. Bioclastic extraclastic grainstone}

The upper part of the carbonate deposits consists of two bioclastic extraclastic grainstone bodies containing rich assemblages of large benthic foraminifers, separated by a 5 $\mathrm{m}$ thick wackestone level (facies A4, Fig. 4). The lower grainstone body is $4 \mathrm{~m}$ thick and overlies the sandstones, while the second one, $12 \mathrm{~m}$ thick, is situated above the wackestone facies. The transition between the sandstones and the lower grainstone level is gradual, preceded by the increasing frequency of grainstone layers within the sandstone. At the boundary between the two facies types the extraclastic input is reduced to about $15-20 \%$ of the total sedimentary material with grain size and shape similar to those described from the sandstones. In fossil assemblages, discocyclinids appear for the first time alongside the nummulitids. Echinoids, fragmented mollusk shells and algal debris are also present. At the base of the grainstones, nummulitids and discocyclinids each represent about $25 \%$ of the total sediments, individuals of both families measuring between $2-4 \mathrm{~mm}$ in diameter. The size of nummulitids remains relatively constant throughout the grainstone facies, but in the lower grainstone body their numbers decrease upward while at the same time there is an increase in the size of discocyclinids that can reach up to $3 \mathrm{~cm}$ in diameter (Pl. I, Fig. 3). In the upper grainstone body, nummulitids are dominant in fossil assemblages, with only a small number of discocyclinids present.

The presence of large and numerous discocyclinids is usually interpreted as an indication of a stable, normal marine environment (Cosovic et al., 2004), and it is generally accepted that larger individuals are commonly found in environments characterized by optimal conditions for a given species (Cosovic and Drobne, 1995). Discocyclinids were described from Eocene carbonates of northern Italy in association with nummulites from the upper part of the outer shelf (Bassi, 2005), while in more distal environments, discocyclinids which could presumably tolerate water depths of up to $100 \mathrm{~m}$ were dominant (Geel, 2000). Based on the distribution of large foraminifers, the lower grainstone body accumulated in a progressively deepening middle ramp environment, with optimal conditions for the development of discocyclinids being reached close to the transition towards facies $\mathrm{A} 4$, while in the upper grainstone unit the net dominance of nummulitids could point towards deposition in somewhat shallower waters.

\section{A4. Rhodolith wackestone/packstone}

A $5 \mathrm{~m}$ thick intercalation of wackestone was identified in the upper part of the carbonate deposits, with texture and fossil assemblages differing significantly from those of the under- and overlying deposits. Siliciclastic input decreases abruptly at the boundary between the wackestones and the underlying grainstone body, and increases again in the overlying grainstones.

Fossil assemblages are dominated by coralline algae (Sprolithon sp., Lithothamnion sp., Mesophyllum sp. and Lithoporella melobesioides), which form rhodoliths or algal crusts (Pl. I, Fig. 4). The surrounding wackestone matrix 


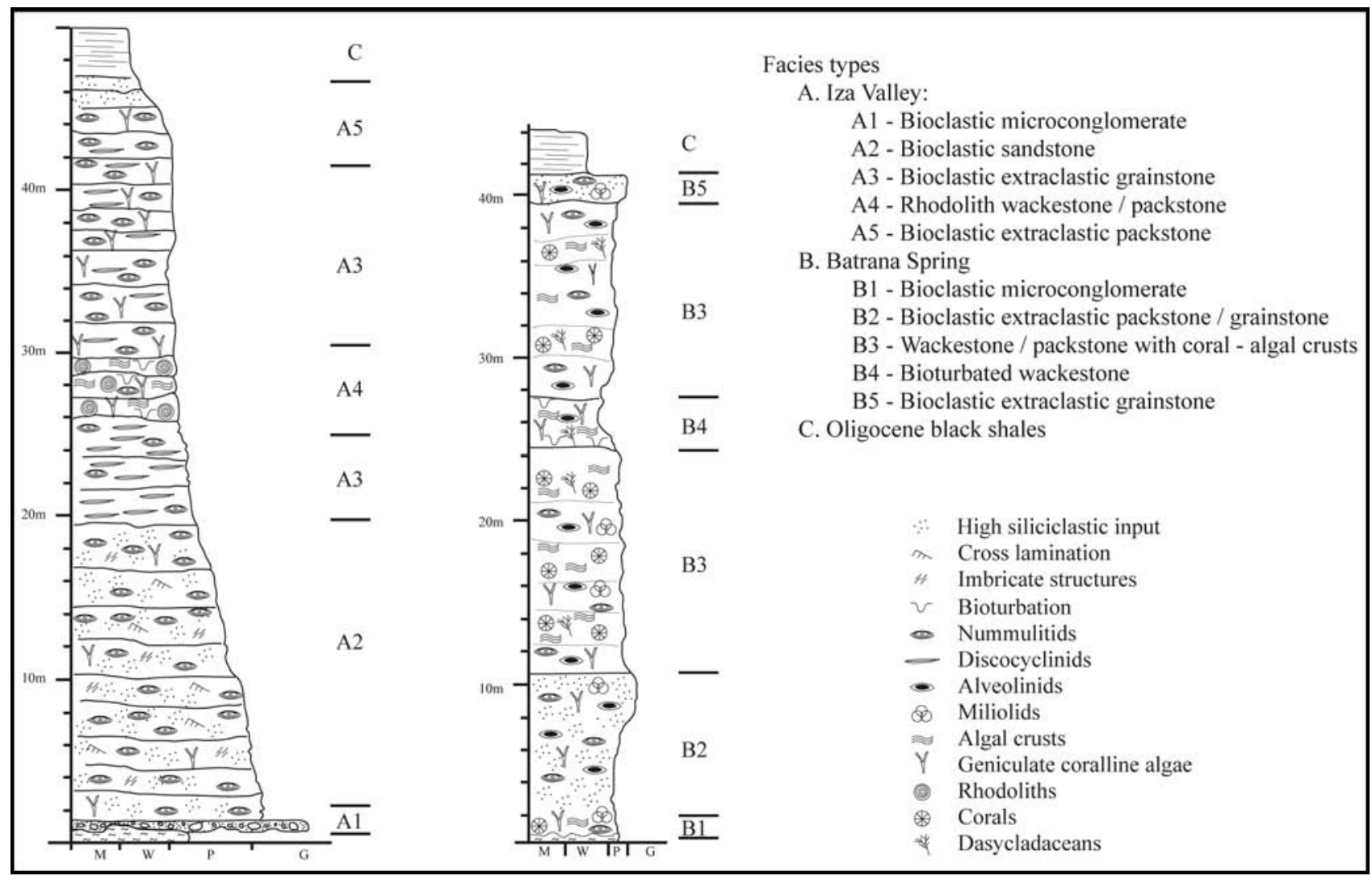

Fig. 4. Lithological succession of the Priabonian limestone: A - Iza Valley, B - Bătrâna Spring.

contains bryozoans, isolated and sometimes poorly preserved large foraminifers, and geniculate coralline algae (Jania sp., Corallina sp.). Rhodoliths have mostly spherical shapes, are macroscopically visible in hand samples, and have diameters of $2-3.5 \mathrm{~cm}$. They are generally non-nucleated and composed of densely packed algal lamina. Algal crusts are oriented horizontally and developed on fine-grained substrates, with small bio- and lithoclasts bound inside the algal framework.

Fossil assemblages consisting of large foraminifers are thought to be restricted to stable, slightly nutrient depleted environments, and normal marine salinity values (Hallock and Glenn, 1986). The highly specialized foraminifers were unable to adapt to environments in which nutrients became readily available, and coralline algae and bryozoans were probably favored under these circumstances (BeavingtonPenney and Racey, 2004). The development of algal crusts requires low substrate mobility and hydrodynamic energy and usually occurs below the wave base, or in shallow, protected environments (Rasser and Piller, 2004). On the other hand, at least moderate hydrodynamic energy is necessary to induce the fragmentation of algal crusts and to provide frequent overturning of the growing rhodoliths. Bassi (1998) interpreted similar deposits containing rhodoliths, coralline algal crust, carbonate mud, and small foraminifers in the Eocene of N Italy, as having been deposited in relatively deep water, in the upper part of the outer ramp, where sediments were occasionally reworked by low frequency but high energy storm events.

\section{A5. Bioclastic extraclastic packstone}

At the top of the bioclastic grainstones (A3) a transition toward a packstone-type facies is marked by a significant increase of extraclastic input. Grain sizes of up to $1 \mathrm{~cm}$ are common towards the top of the Iza Valley section. Fossil assemblages consist of nummulitids, nodosariids and other benthic genera, echinoids, and fragments of coralline algae (Pl. I, Fig. 5). In the uppermost 1-2 $\mathrm{m}$ of the sampled section, a rich association of bivalves, dominated by ostreids and pectinids was identified. Bivalves presumably colonized a large portion of the carbonate shelf, as their presence can be traced inside a radius of more than $2 \mathrm{~km}$ in all the outcrops that expose the top of the limestone. Shells are generally disarticulated, but individual valves tend to be well preserved, with ornamentations clearly visible in the case of pectinids.

The gradually increasing extraclastic input and the presence of large bivalve colonies at the top of the limestones indicate an upward-shallowing environment, with deposition close to, or above the FWWB, where high hydrodynamic energy led to the disarticulation of the bivalve shells.

\section{Bătrâna Spring section}

The carbonate deposits are $41 \mathrm{~m}$ thick, and five facies types were identified (B1 to B5 in Fig. 4). The base and top of the limestones consist of extraclastic packstones and grainstones, while its middle and upper part comprises alternating wackestones and packstones with several coral and coralline algal crusts which form a massive structure, lacking obvious bedding planes.

\section{B1. Bioclastic microconglomerate}

Similarly to the Iza Valley section, the erosional contact between the metamorphic basement and the Priabonian limestone is marked by a micro-conglomerate layer with a thickness of approximately $0.5 \mathrm{~m}$. Extraclastic material 
consists of quartz pebbles with angular to subangular shapes and up to $1 \mathrm{~cm}$ in diameter and quartz sand. Benthic foraminifers are represented by scattered miliolids, alveolinids, and Chapmanina sp., accompanied by fragments of geniculate (Amphiroa sp.) and non-geniculate (Lithoporella melobesioides) coralline algae and coral fragments (Pl. I, Fig. 6).

The deposits accumulated in a high-energy shore/inner ramp environment and may be an equivalent of the A1 facies from the Iza Valley section. The main difference between the two facies types is the presence of coral fragments in the Bătrâna Spring section.

\section{B2. Bioclastic extraclastic packstone/grainstone}

The basal microconglomerates are vertically replaced by an alternation of 5-10 $\mathrm{cm}$ wackestone and packstone layers, approximately $6 \mathrm{~m}$ thick. Extraclastic input is present in the lower part of the facies, with sand-sized quartz grains, and decreases in size to silt particles near the top. Fossil assemblages (Pl. II, Fig. 1) are dominated by benthic foraminifers, among which perforate forms (alveolinids) are common, but agglutinated genera also occur. Coral debris often encrusted by coralline algae (? Lithothamnion sp.) are restricted to the lower part of the facies, above the basal microconglomerates. Geniculate corallines (Amphiroa sp.) and peyssonneliaceans (Polistrata alba) have also been identified. A gradual transition towards coarser, grainstone-type deposits occurs near the top of the packstones. The grainstones form a $3 \mathrm{~m}$ unit, similar in terms of composition and fossil assemblages to the underlying packstones.

The relatively wide range of identified textures, together with the fossil assemblages point towards an environment in which hydrodynamic energy was variable, but generally low. Open marine conditions probably dominated, and the deposits accumulated below the FWWB, at a sufficient distance from the shoreline so that the effects of the relatively high siliciclastic input, which marks the Iza Valley carbonate sequence, were not felt.

\section{B3. Wackestone/packstone with coral - algal crusts}

The upper $30 \mathrm{~m}$ of the Bătrâna Spring section consist of an alternation between millimetric to $10-15 \mathrm{~cm}$ layers of packstone and wackestone (Pl. II, Fig. 2). During times of low sediment input, the soft substrate was colonized by corals and encrusting algae, which were buried when sediment influx increased. Small voids (0.5-1.5 $\mathrm{mm}$ diameter) were observed inside the packstones and at the packstone/wackestone transitions, usually filled with fine grained sediment and carbonate mud. The voids are occasionally lined by crusts of possible microbial origin, whose development could be controlled by the decay of organic matter in the accumulating sediment. Fossil assemblages are diverse, with benthic foraminifers including miliolids, nummulitids, alveolinids, and small discocyclinids, along with geniculate coralline algae (Amphiroa sp, Corallina sp.), bryozoans, echinoids, and small gastropods.

Algal crusts consisting of non-geniculate corallines (Lithoporella melobesioides, Mesophyllum sp, Lithothamnion sp, Lithophyllum sp.) and peyssonneliaceans (Polistrata alba), common throughout the deposits, formed either directly on the sedimentary substrate or on larger bioclasts (Pl. II, Fig. 3). In both cases, the crusts are up to 1-2 mm thick and show several continuous laminae. In vertical succession, in situ preserved corals form 4-5 distinct levels with small encrusting colonies $(10-15 \mathrm{~cm}$ in height) developed over soft substrates (Pl. II, Fig. 4), but coral debris are visible in almost all thin sections. Voids within the coral structure are filled by fine-grained sediments, in which occur occasional Dasycladaceans, identified as Thyrsoporella sp. and possibly Neomeris sp.

Algal crust diversity is due to the presence of both coralline Lithothamnion, which preferentially encrusts coarse grained particles, and peyssonneliacean algae, capable of forming crusts on soft substrates (Rasser and Piller, 2004). The development of algal crusts requires a low-energy setting and the presence of corals points toward low water turbidity. However, occasional increases of the accumulation rate of fine grained sediment may lead to repeated burial of the encrustations covering the sea floor. The presence of LBF assemblages consisting of small nummulitids, alveolinids, and discocyclinids indicates shallow protected environments in back reef settings (Geel, 2000). The abundant coral debris found within the sediments could also indicate proximity to a reef structure, although no such feature was actually sampled.

\section{B4. Bioturbated wackestone}

The relatively constant conditions that characterized the sedimentation of facies B3 were temporarily interrupted, resulting in the accumulation of a $4 \mathrm{~m}$ thick wackestone intercalation towards the middle part of the deposits described above (B4 in Fig. 4). Fossil remains found within this unit are restricted to mollusk shell fragments and partially dissolved corals, fragments of geniculate (Amphiroa sp.) and non-geniculate corallines (Lithoporella melobesioides and Mesophyllum sp.) and fragments of halimedacean green algae. The sea floor was inhabited by ostracods and small gastropods, which caused intense bioturbation of the fine-grained sediments (PI. II, Fig. 5).

Facies B4 appears to have been deposited in more restrictive conditions compared to the under- and overlying deposits of facies B3. Corals and benthic foraminifers, restricted to normal marine conditions and abundant in facies B3 are replaced by organisms that tolerate a wider range of environments, like ostracods and gastropods.

\section{B5. Bioclastic extraclastic grainstone}

While sedimentation of the Bătrâna Spring section took place under relatively low-energy conditions, a transition towards a more dynamic environment occurs near the top of the carbonate deposits. Siliciclastic input shows a marked increase compared to the rest of the section, with quartz sands and pebbles becoming more common. Fossil assemblages include benthic foraminifera (nummulitids, alveolinids, and miliolids), echinoid plates, coralline algae (Amphiroa sp., Lithoporella melobesioides, Mesophyllum) and peyssonneliaceans (Polistrata alba). This facies may be an equivalent of facies A5 from the Iza Valley section and was accumulated in a high-energy environment, the presence of coarse siliciclastic material indicating deposition in the relative proximity of the seashore. 


\section{Oligocene black shales}

In most surface outcrops in the study area the Priabonian limestone is overlain by lower Oligocene black shales, belonging to the Valea Carelor formation. The shales consist of well bedded, dark colored clays, in which thin sections showed several milimetric to centimetric intercalations of mainly quartzitic sandy material (Pl. II, Fig. 6). The contact between the shales and limestones is exposed both at the surface and in passages of the Iza Cave (Tămaş, in press). The contact between the two lithologies is clearly marked in the outcrops from the Iza Valley. Further south in the Bătrâna Spring area, an approximately $1 \mathrm{~m}$ layer of interbedded limestones and black shales constitutes a more gradual transition between the two formations.

\section{DEPOSITIONAL ENVIRONMENT}

The distribution of Eocene deposits in the study area and in the neighboring depressions suggests that the Rodnei Mountains were already established as a positive topographic feature during the Late Eocene. Shallow-water carbonates are found both on the northern and southern slopes of the massif, while the deeper parts of the Eocene sedimentary basin are marked by flysch type sediments (Patrulius et al., 1968).

Relative sea-level change is the main factor controlling the distribution of facies zones in carbonate environments (Geel, 2000; Murray, 2001). The chronology of relative sealevel change in the intra-Carpathian area was estimated based on the Paleogene sedimentary record of the Transylvanian basin (Proust and Hosu, 1996) and shows opposite long-term trends compared to the global sea-level curve of Haq et al. (1987). Short-term variations on the other hand seem to match those of the global curve, so that the Upper Eocene is characterized by a general trend of sealevel fall, with several positive oscillations.

The accumulation of the studied carbonate deposits took place during a transgressive - regressive cycle, indicated by an upward-deepening trend recorded in the lower half of the Iza Valley section and the presence of a shallow inner ramp facies at the top of both sections (Fig. 5).

Both sampled sections start with basal microconglomerates (facies A1 and B1) that erosionally overlie the crystalline basement of the Rodnei Mountains and were deposited in shoreface environments.

A relative sea-level rise marks the transition towards facies types A2 and B2, which accumulated in an inner ramp and upper mid-ramp setting respectively. In the northern part of the carbonate ramp (Iza Valley) sediments were deposited in a mixed carbonate-siliciclastic environment, above the FWWB. Good sorting and the lack of carbonate mud indicate constant reworking by waves. In the southern part of the ramp (Bătrâna Spring section) accumulation took place in a more distal and/or deeper setting, below the FWWB in a carbonate environment lacking siliciclastic input. LBF associations are present both in A2 and B2 facies, but while the nummulitic shoals of the Iza Valley sequence were subjected to repeated winnowing and/or transport, the fossil associations of facies B2 more likely record an undisturbed biocenosis. The increased frequency of grainstone intercalation toward the top of facies A2 indicates a progressive deepening of the depositional environment in the northern part of the ramp, with mid-ramp Studia UBB, Geologia, 2008, 53 (2), 13 - 24

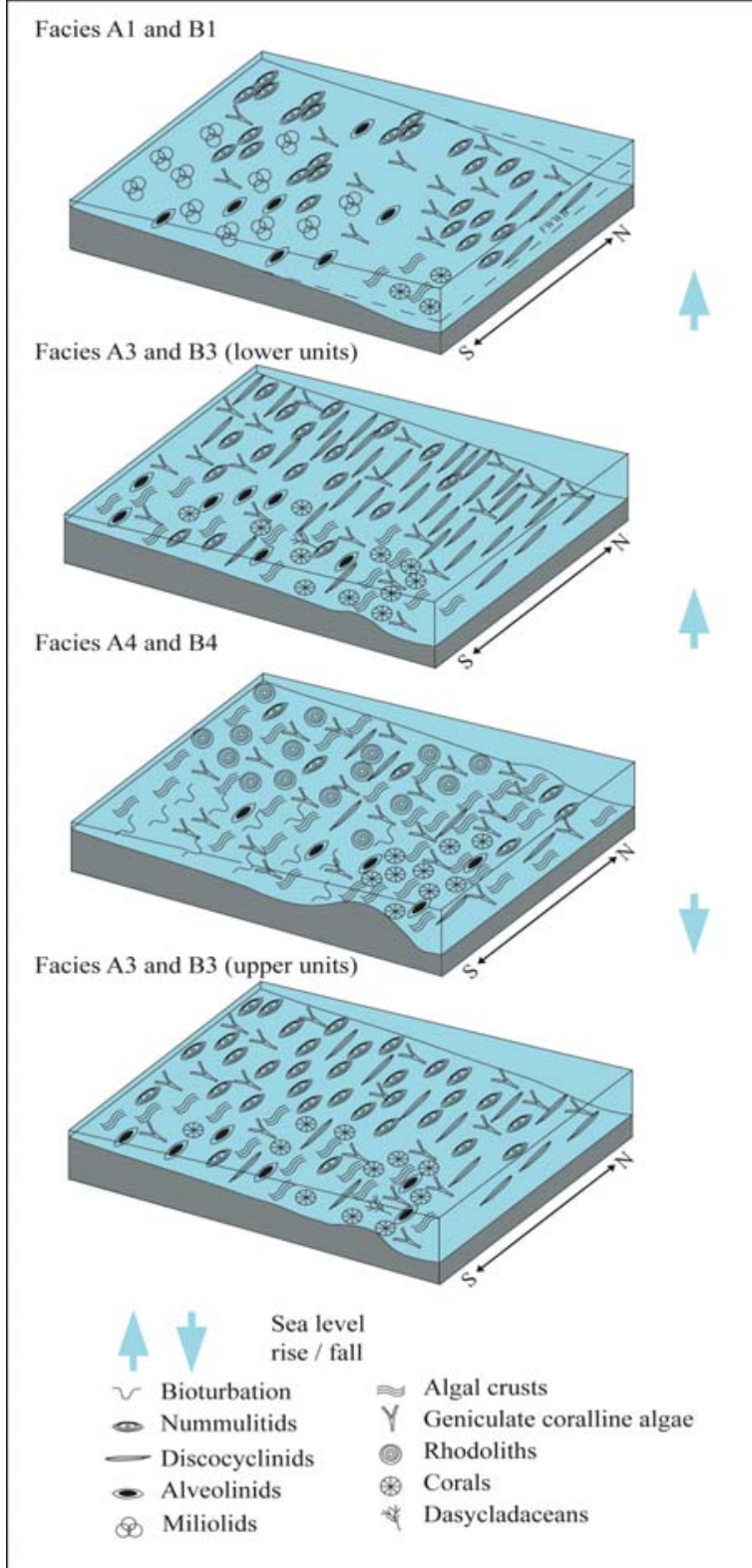

Fig. 5. Evolution of depositional environments across the Priabonian carbonate ramp.

grainstones (A3) rich in nummulitids and discocyclinids. In the southern part of the ramp, sedimentation rates seem to keep up with rising sea levels but a transition from the open marine deposits (facies B2) to a more sheltered, back-reef environment (facies B3) is indicated by the presence of nummulitid - alveolinid - discocyclinid associations and the presence of coral fragments.

Facies A4 and B4 are wackestone intercalations in the upper parts of both studied sections. LBF assemblages show a strong decline and are replaced by red algae in facies A4. In facies B4 corals and algal crusts are replaced by colonies of ostracods and small gastropods. Fossil assemblages point towards a stage of temporary isolation of the carbonate shelf, after which the return to open marine conditions is signaled by the re-appearance of the deposits of facies A3 and $\mathrm{B} 3$ respectively.

According to Geel (2000), temporary isolation can occur during the early stages of marine high-stand, as long as accumulation of sediments keeps up with, or even outpaces, the rate at which new accommodation space is created. An effective barrier, consisting of corals and bioclastic material 
bound by algal crusts could have formed, particularly in the southern part of the carbonate ramp, and would significantly limit the connections with open sea environments. During the same time, surface runoff could reduce salinity below the tolerance level of the large benthic foraminifera, providing increased nutrient levels which facilitated the development of algal crusts and subsequently rhodoliths in facies A4. Similarly, in facies B4 corals and benthic foraminifers are replaced by organisms, which could adapt to the environmental changes caused by a temporary isolation of the carbonate shelf.

The two uppermost facies, A5 and B5, which occur at the top of the two sampled sedimentary logs, are both characterized by a relatively high siliciclastic input, which indicates a relative sea level fall. In facies A5, the large bivalve colony developed in a shallow environment, with a hard substrate, which provided suitable attachment surfaces for the ostreids and pectinids.

The lower part of the two studied sections (facies types A1, B1, A2, B2 and the lower units of A3 and B3) constitutes an upward deepening series, with the maximum flooding of the carbonate ramp recorded in facies A4 and B4 (Fig. 5). The upper units of facies A3 and B3, and respectively A5, B5 show a regressive marine trend, with depositional environments shifting from mid- to inner-ramp settings, in agreement with the general trend of sea-level fall at the end of the Eocene in the study area.

At the Eocene/Oligocene boundary, carbonate sedimentation at the sampled sites was interrupted by the deposition of black shales. Organic carbon rich sediments are widespread both in the NW Rodnei Mountains and in adjacent areas, and similar deposits occur both in the Transylvanian depression, and in the Outer Carpathian flysch. On a large scale, the deposition of black shales during the lower Oligocene is seen as a basin-wide phenomenon, which accompanied the first separation of the Paratethys Ocean and the present day Mediterranean Sea (Schultz et al., 2005). Normal marine conditions, which prevailed during the Eocene, were replaced by a restricted circulation pattern (Rögl, 1999), which led to the vertical stratification of the water column and photic zone anoxia (Schmiedl et al., 2002) due to the dilution of the marine water body by continental runoff (Schultz et al., 2002).

\section{CONCLUSIONS}

During the Priabonian, shallow-water carbonates were deposited in the NW Rodnei Mountains, over a basement consisting of Precambrian metamorphic rocks and Lutetian conglomerates. Two sections were sampled within the limestone which appears as a continuous NW-SE oriented monoclonal structure. 10 facies types were identified, ranging from upper shoreface to mid-ramp deposits, with relative sea level rise seen as the main factor controlling carbonate sedimentation. In the northern part of the carbonate ramp, large benthic foraminifers dominated fossil assemblages, while in the southern part of the study area coralline algae and corals constituted major sediment contributors.

The lower part of the carbonate deposits consists of a transgressive series in which basal microconglomerates (A1) are overlain by inner ramp bioclastic sandstones (A2) and mid-ramp grainstones (A3) in the northern part of the ramp. In the southern part of the ramp, mid-ramp packstones and wackestones with coral and algal crusts (B2, B3) overlie the the basal conglomerates. Temporary isolation of the carbonate ramp occurred during an episode of maximum flooding recorded in facies A4 and B4, followed by a regressive trend in which mid-ramp deposits (A3 and B3) are overlain by inner-ramp sediments (A5, B5).

Carbonate sedimentation ceased in the study area at the Eocene/Oligocene Boundary, when eutrophication of the depositional environment and restrictive circulation patterns led to the deposition of black shales on a basin-wide scale.

Acknowledgements. This work has benefited from the help of Dan Călean, Alina Gînsac, and Iuliana Vişan, who assisted during fieldwork. Thanks are due to Prof. Ioan Bucur, for identifying algal species and helpful discussions. Felix Schlagintweit and an anonymous reviewer are thanked for their constructive remarks that greatly improved the manuscript. This paper is the second scientific contribution to the Iza Cave Project.

\section{R E F E R E N C E S}

Aigner, T. 1985, Biofabrics as dynamic indicators of nummulite accumulations. Journal of Sedimentary Petrology, 55: 131-134.

Allen, P.A., Burgess, P.M., Galewsky, J. \& Sinclair, H.D. 2001, Flexural-eustatic numerical model for drowning of the Eocene perialpine carbonate ramp and implications for Alpine geodynamics. Geological Society of America Bulletin, 113 (8): 1052-1066.

Aroldi, C. 2001, The Pienides in Maramureş: sedimentation, tectonics and paleogeography. Cluj University Press, Cluj-Napoca, 156 p.

Baldi, T. 1986, Mid-Tertiary stratigraphy and paleogeographic evolution of Hungary. Akademiai Kiado, Budapest, 201 p.

Balintoni, I. 1997, Geotectonica terenurilor metamorfice din România. Ed. Carpatica, Cluj Napoca, 176 p.

Barattolo, F., Bassi, D. \& Romano, R. 2007, Upper Eocene larger foraminiferal-coralline algal facies from the Klokova Mountain (southern continental Greece). Facies, 53: 361-375.

Bassi, D. 1998, Coralline algal facies and their palaeoenvironments in the Late Eocene of Northern Italy (Calcare di Nago, Trento). Facies, 39: 179-202.

Bassi, D. 2005, Larger foraminiferal and coralline algal facies in an Upper Eocene storm-influenced, shallowwater carbonate platform (Colli Berici, north-eastern Italy). Palaeogeography, Palaeoclimatology, Palaeoecology, 226: 17-35.

Beavington-Penney, S.J., Racey, A. 2004, Ecology of extant nummulitids and other larger benthic foraminifera: applications in palaeoenvironmental analysis. Earth Science Reviews, 67: 219-265.

Buxton, M.W.N., Pedley, H.M. 1989, Short paper: a standardized model for Tethyan Tertiary carbonate ramps. Journal of the Geological Society, 146: 746-748.

Cosovic, V., Drobne, K. 1995, Palaeoecological significance of morphology of orthophragminids from the Istrian Peninsula (Croatia and Slovenia). Geobios, 18: 93-99.

Cosovic, V., Drobne, K. \& Moro, A. 2004, Paleoenvironmental model for Eocene foraminiferal limestones of the Adriatic carbonate platform (Istrian Peninsula). Facies, 50: 61-75. 
Csontos, L., Nagymarosy, A. 1998, The Mid-Hungarian line, a zone of repeated tectonic inversions. Tectonophysics, 297: 51-71.

Dicea O., Duţescu P., Antonescu, F., Mitrea, G., Botez, R., Donoş, I., Lungu, V. \& Moroşanu, I. 1980, Contribuţii la cunoaşterea stratigrafiei zonei transcarpatice din Maramureş. Dări de seama ale Institutului de Geologie şi Geofizică, LXV (4): 21-85.

Geel, T. 2000, Recognition of stratigraphic sequences in carbonate platform and slope deposits: empirical models based on microfacies analysis of Paleogene deposits in southern Spain. Palaeogeography, Palaeoclimatology, Palaeoecology, 155: 211-238.

Hallock, P., Glenn, E.C. 1986, Larger foraminifera: a tool for paleoenvironmental analysis of Cenozoic carbonate depositional facies, Palaios, 1 (1): 55-64.

Haq, B.U., Hardenbol, J. \& Vail, P.R. 1987, Chronology of fluctuating sea levels since the Triassic. Science, 235: 1156-1167.

Hohnegger, J., Yordanova, E., Hatta, A. 2000, Remarks on west Pacific Nummulitidae (Foraminifera), Journal of Foraminiferal Research, 30 (1): 3-28.

Jorry, J.S., Davaud, E. \& Caline, B. 2003, Controls on the distribution of nummulite facies: a case study from the late Ypresian El Garia formation (Kesra Plateau, Central Tunisia). Journal of Petroleum Geology, 26 (3): 283-306.

Jorry, J.S., Hasler, C.A. \& Davaud, E. 2006, Hydrodynamic behaviour of Nummulites: implications for depositional models. Facies, 52: 221-235.

Kazmer, M., Dunkl, I., Frisch, W., Kuhlemann, J. \& Ozsvart, P. 2003, The Paleogene forearc basin of the Eastern Alps and Western Carpathians: subduction, erosion and basin evolution. Journal of the Geological Society, London, 60: 413-428.

Kiessling, W., Flügel, E. \& Golonka, W. 2003, Patterns of Phanerozoic carbonate sedimentation. Lethaia, 36: 195-226.

Kräutner, H.G., Kräutner, F. \& Szasz, L. 1982, Harta geologică 1:50.000, foaia 20a, Pietrosul Rodnei. Institutul de Geologie şi Geofizică, Bucureşti.

Krezsek, C., Bally, A.W. 2006, The Transylvanian Basin (Romania) and its relation to the Carpathian fold and thrust belt: Insights in gravitational salt tectonics. Marine and Petroleum Geology, 23 (4): 405-442.

Murray, J.W. 2001, The niche of benthic foraminifera, critical thresholds and proxies. Marine Micropaleontology, 41: 1-7.

Mutihac, V. 1955, Cercetări geologice în regiunea dintre Cristalinul Rodnei şi Masivul eruptiv al Ţibleşului. Dări de seamă ale şedinţelor Comitetului Geologic, XXXIX (1951-1952), 113-122.

Mutihac, V. 1990, Structura geologică a teritoriului României. Ed. Tehnică, Bucureşti, 424 p.

Nebelsick, J.H., Rasser., M.W. \& Bassi, D. 2005, Facies dynamics in Eocene to Oligocene circumalpine carbonates. Facies, 51:197-216.

Oberhauser, R. 1995, Zur Kenntnis der Tektonik und der Paläogeographie des Ostalpenraumes zur Kreide-, Paleozän- und Eozänzeit. Jarbuch der Geologischen Bundesanstalt, 138: 369-432.

Oszczypko, N. 2006, Late Jurassic-Miocene evolution of the Outer Carpathian fold-and-thrust belt and its foredeep basin (Western Carpathians, Poland). Geological Quarterly, 50 (1): 169-194.
Patrulius, D., Dimitrescu, R. \& Bleahu, M. 1955, Cercetări geologice în Valea Vişeului şi în împrejurimile Săcelului (Maramureş). Dări de seamă ale Şedinţelor Comitetului Geologic al RPR, XXXIX (1951-1952), 96-127.

Patrulius, D., Bombiţă, G., Kräutner, H.G. \& Kräutner, F. 1968, Harta geologică scara 1:200.000, foaia 4, Vișeu. Comitetul de Stat al Geologiei, Institutul Geologic Bucureşti.

Philip, J. 2003, Peri-Tethyan neritic carbonate areas: distribution through time and driving factors. Palaeogeography, Palaeoclimatology, Palaeoecology, 196: 19-37.

Proust, J.N., Hosu, A. 1996, Sequence stratigraphy and Paleogene tectonic evolution of the Transylvanian Basin (Romania, Eastern Europe). Sedimentary Geology, 105: 117-140.

Racey, A. 2001, A review of Eocene nummulite accumulations: structure, formation, and reservoir potential. Journal of Petroleum Geology, 24 (1): 79-100.

Rasser, M.W. 2000, Coralline algal limestones of the Late Eocene Alpine Foreland Basin in Austria: component analysis, facies and paleoecology. Facies, 42: 59-92.

Rasser, M.W., Piller, W.E. 1997, Depth distribution of calcareous encrusting associations in the northern Red Sea (Safaga, Egypt) and their geological implications. Proceedings of the $8^{\text {th }}$ International Reef Symposium, Panama: 743-748.

Rasser, M.W., Piller, W.E. 2004, Crustose algal frameworks from the Eocene Alpine Foreland. Palaeogeography, Palaeoclimatology, Palaeoecology, 206: 21-39.

Rögl, F. 1999, Mediterranean and Paratethys. Facts and hypotheses of an Oligocene to Miocene paleogeography (short overview). Geologica Carpathica, 50 (4): 339-349.

Schmiedl, G., Scherbacher, M., Bruch, A., Jelen, B., Nebelsick, J.H., Hemleben, C., Mosbrugger, V. \& Rifelj, H. 2002, Paleoenvironmental evolution of the Paratethys in the Slovenian Basin during the Late Paleogene. International Journal of Earth Sciences, 91: 123-132.

Schmid, S.M., Fügenschuh, B., Kissling, E. \& Schuster, R. 2004, Tectonic map and overall architecture of the Alpine orogen. Eclogae Geologicae Helvetiae, 97: 93-117.

Schulz, H.M., Sachsenhofer, R.F., Bechtel, A., Polesny, H. \& Wagner, L. 2002, The origin of hydrocarbon source rocks in the Austrian Molasse Basin (Eocene - Oligocene transition). Marine and Petroleum Geology, 19: 638-709.

Schulz, H.M., Bechtel, A. \& Sachsenhofer, R.F. 2005, The birth of the Paratethys during the Early Oligocene: From Tethys to an ancient Black Sea analogue? Global and Planetary Change, 49: 163-176.

Tămaş, T. in press, The Iza karst system revisited (1977 2007 ) - exploration and survey. Proceedings of the $6^{\text {th }}$ Symposium on karst protection, Belgrade 2007, Serbia.

Tămaş, T., Häuselmann, P., Sahy, D. \& Pop, M. 2008, Preliminary results on the geology and evolution of the Iza Cave (Rodnei Mountains, N Romania). Geophysical Research Abstracts, Vol. 10, EGU2008-A-10567.

Tischler M. 2005, A combined structural and sedimentological study of the Inner Carpathians at the northern rim of the Transylvanian basin (N. Romania). Unpublished $\mathrm{PhD}$ Thesis, University of Basel, $136 \mathrm{p}$.

Viehmann, I., Silvestru, E. \& Fabian, C. 1979, La Grotte d'Iza, Monts de Rodna, Roumanie. Travaux de l'Institut de Spéologie “Emil Racovitza”, XVIII: 201-207. 
PLATE I

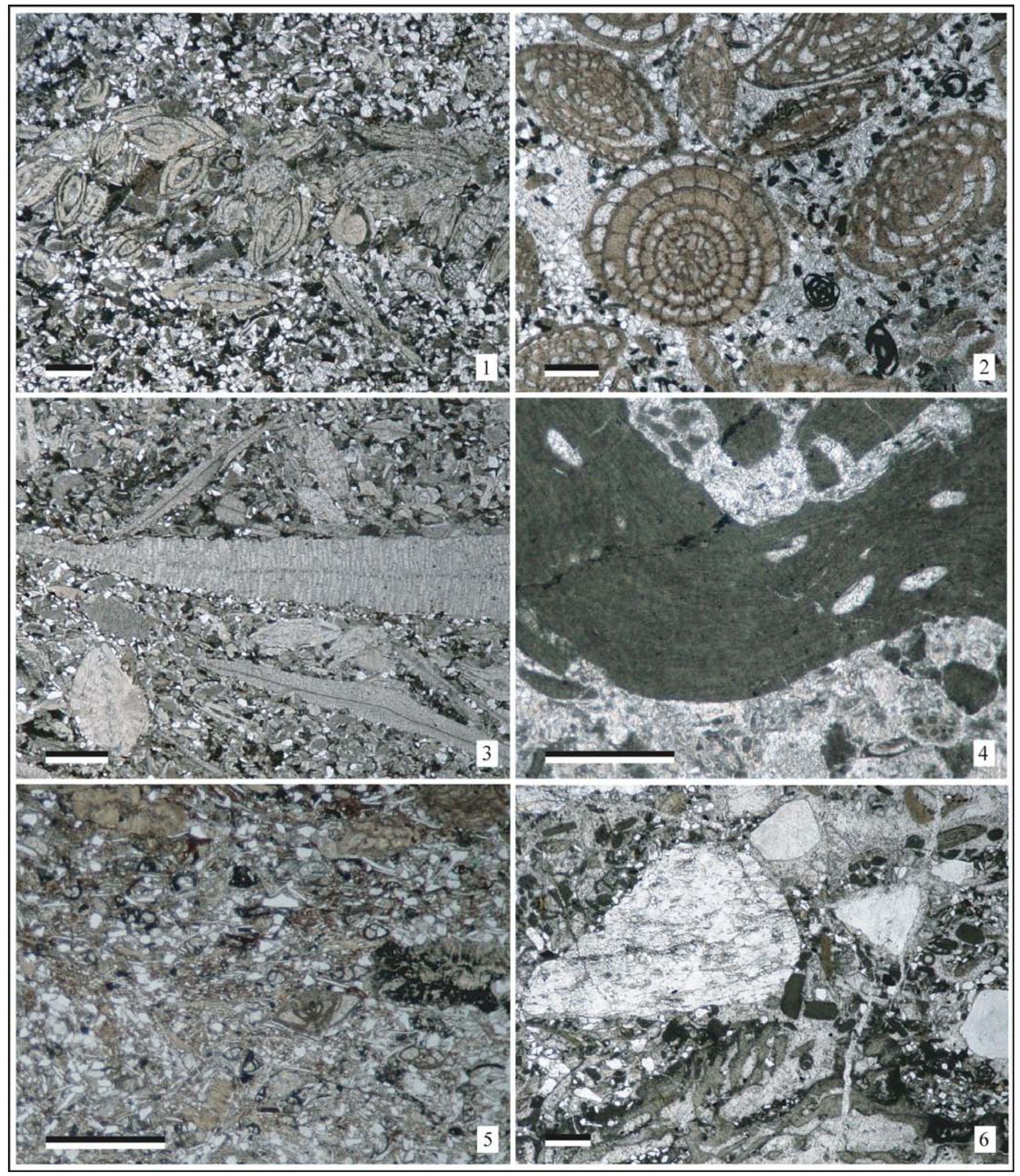

Figs. 1, 2. Nummulitic shoals found within the bioclastic sandstones in facies A2 (Iza Valley).

Fig. 3. Grainstone with large discocyclinids associated with smaller, lenticular nummulitids in facies A3 (Iza Valley).

Fig. 4. Wackestone with red algae and bryozoans from facies A4 (Iza Valley).

Fig. 5. Bioclastic packstone containing small foraminifers near the top of the Iza Valley limestone (facies A5).

Fig. 6. Micro-conglomerate containing quartz and quartzite clasts and large coral and algal fragments at the base of the Bătrâna Spring limestone (facies B1). 
PLATE II
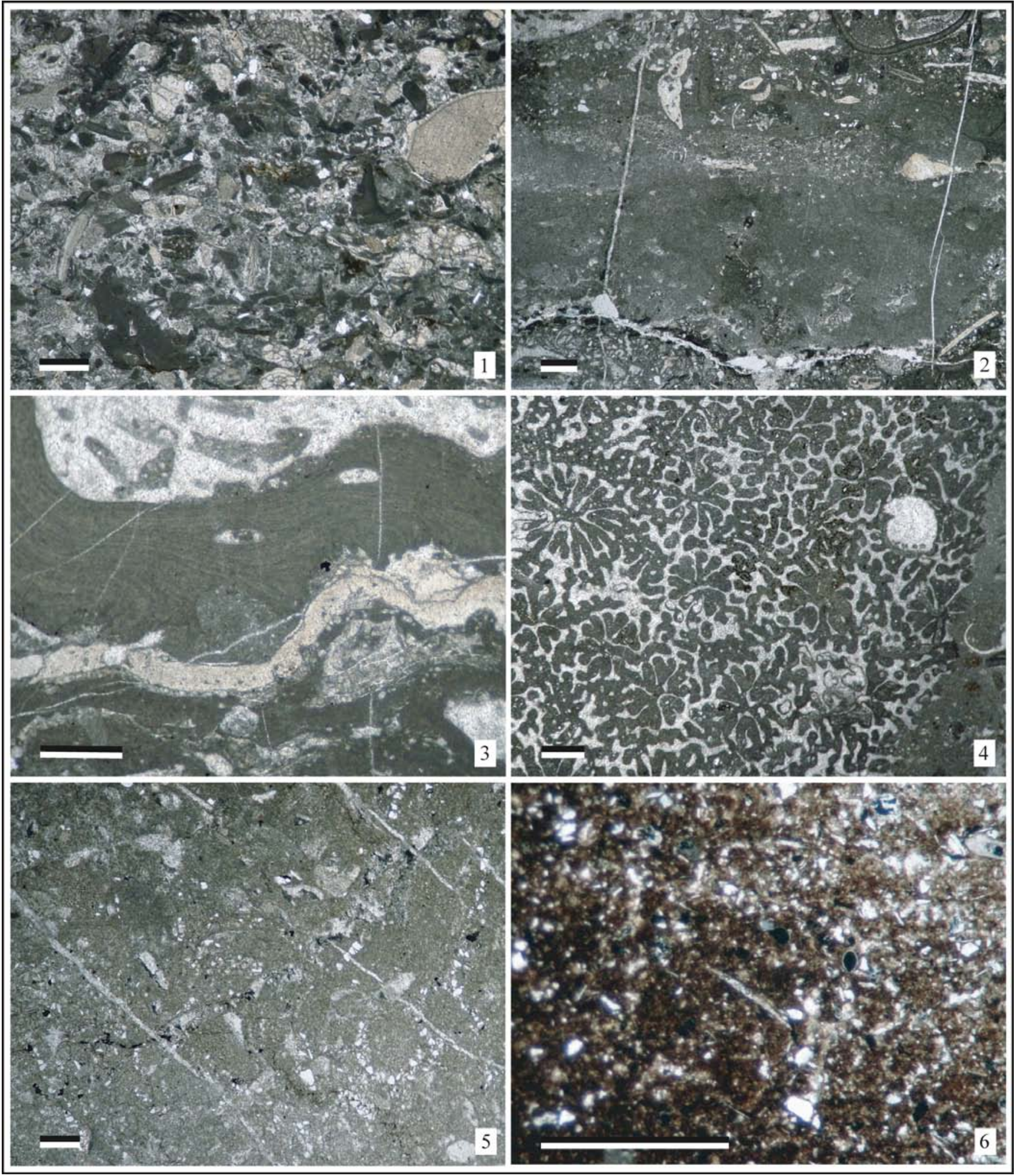

Fig. 1. Bioclastic packstone (B2) containing small benthic foraminifers, bryozoans, red algae, and echinoid plates (Bătrâna Spring).

Fig. 2. Alternations between 4-5 mm layers of wackestone and packstone in facies B3 (Bătrâna Spring).

Fig. 3. Red algae encrusting coral fragments and lithoclasts in facies B3 (Bătrâna Spring).

Fig. 4. Coral branches subsequently buried by fine-grained sediments in facies B3 (Bătrâna Spring).

Fig. 5. Wackestone with traces of intense bioturbation in facies B4 (Bătrâna Spring).

Fig. 6. Transition between quartz-rich and clay dominated laminae in the Oligocene black shales. 